\title{
ПРО ПІДГОТОВКУ ПРОВІЗОРІВ ТА ПРОВІЗОРІВ-ОРГАНІЗАТОРІВ НА КУРСАХ ПІДИЩЕННЯ КВАЛІФІКАЩІЇ НА БАЗІ ФАКУЛЬТЕТУ ПІСЛЯДИПЛОМНОЇ ОСВІТИ
}

\author{
І. М. Білай, В. І. Дарій, О. А. Рижов, С. С. Пругло, Т. С. Райкова, І. В. Бушуєва, \\ Т. П. Зарічна, В. О. Демченко, М. В. Білоус, Н. В. Кандибей \\ Запорізький державний медичний університет
}

\section{THE TRAINING OF PFARMACEUTICAL CHEMISTS AND PHARMACEUTICAL CHEMISTS-ORGANIZERS AT IMPROVEMENT OF PROFESSIONAL SKILL COURSES ON THE BASIS OF POST-GRADUATE EDUCATION FACULTY}

\author{
I. M. Bilay, V. I. Dariy, O. A. Ryzhov, Ye. S. Pruhlo, T. S. Raykova, I. V. Bushuyeva, \\ T. P. Zarichna, V. O. Demchenko, M. V. Bilous, N. V. Kandybey \\ Zaporizhian State Medical University
}

\begin{abstract}
У роботі показана підготовка провізорів та провізорів-організаторів на курсах підвищення кваліфікації на базі факультету післядипломної освіти Запорізького державного медичного університету.
\end{abstract}

The training of pharmaceutists and pharmaceutical chemists - organizers at improvement of professional skill courses on the basis of post - graduate education faculty in Zaporizhian State Medical University has been presented in the artide.

Вступ. Система післядипломного навчання - невід'ємна частина концепції безперервної фармацевтичної освіти, яка дозволяє ефективно використовувати досягнення науково-технічного прогресу в галузі фармації та інших галузях з підвищення рівня професійної підготовки, удосконалення знань, умінь, особових іпрофесійних якостей фахівців фармації [1-7].

Основна частина. В умовах ринкових реформ перехід на якісний рівень медичної та фармацевтичної галузей, перш за все, пов' язаний з вимогами підготовки систематичного удосконалення кадрів, які здатні вирішувати різноманітні і складні питання сьогоднішнього дня.

Провізор повинен інтегрувати в собі комплекс знань і умінь з питань створення, збереження, реалізації та застосування лікарських засобів. Вирішальна роль належить вмінню провізора в умовах ринкової економіки своєчасно, якісно та ефективно забезпечувати населення і лікувально-профілактичні заклади лікарськими препаратами.

Таким чином, професійна компетентність i здатність вирішувати професійні проблеми не можуть бути повністю забезпечені знаннями, отриманими в період навчання у вищому навчальному закладі. Тому ( I. М. Білай, В. І. Дарій, О. А. Рижов та ін. процес удосконалення та оновлення професійних знань і умінь повинен бути постійним.

У зв’язку з цим, наказом МО3 України № 818 від 12.12.2006p. "Про вдосконалення атестації провізорів та фармацевтів”, фахівці фармацевтичного профілюзобов’язані кожні 5 років підвищувати ділову кваліфікацію шляхомнавчання на курсах удосконалення. Особи, яким присвосна кваліфікаційна категорія, проходять атестацію на iї підтвердження не рідше одного разу на 5 років.

Провізор повинен отримати широку науково обгрунтовану практичну підготовку, досконало володіти своєю спеціальністю, постійно поповнювати свої знання, розширювати світогляд, вміти на практиці застосовувати наукові принципи маркетингу та менеджменту, володіти передовими методами управління трудовим колективом, вирішувати професійні завдання в галузі забезпечення населення і лікувально-профілактичних закладів лікарськими засобами і т. д.

У Запорізькому державному медичному університеті курси підвищення кваліфікації провізорів та фармацевтів проводяться з 1998 року. За ці 10 навчальних років був створений деканат післядипломної освіти (1999 рік) та кафедра післядипломної освіти 3 фармації (2004 рік). У 2007 році на післядипломному 
етапі було створено дві окремі фармацевтичні кафедри - кафедру клінічної фармації, фармакотерапії і управління та економіки фармації, а також кафедру фармакогнозії, фармацевтичної хімії та технологіїліків. Цепов'язано з метою вдосконалення підготовки провізорів-інтернів та післядипломного підвищення кваліфікації провізорів і фармацевтів (наказ ректора Запорізького державного медичного університету № 61 від 21 березня 2007 року “Про утворення та реорганізацію кафедр фармації ФПО”).

За 2007-2008 навчальний рік розроблені робочі програми з клінічної фармації і управління та економіки фармації для проведення передатестаційних курсів провізорів за спеціальностями “Загальна фармація”, “Організація та управління фармацією”, “Аналітично-контрольна фармація”, а також проведення тематичних курсів "Сучасний стан законодавчого регулювання фармацевтичної діяльності”, “Фармакотерапія окремих захворювань систем організму людини" (78 годин, 2 тижні).

На кафедрі клінічної фармації та УЕФ ФПО підготовлено:

1. Навчально-методичний посібник для практичних занять з фармакотерапії для курсів підвищення кваліфікації.

2. Навчально-методичний посібник для провізорівкурсантів “Фітофармакологія засобів, що впливають на функцію органів дихання і травлення".

3. Навчальний посібник для провізорів-курсантів "Клінічна фармакологія в ревматології. Нестероїдні протизапальні препарати".

4. Методичні рекомендації для виконання практичної роботи слухачам і курсів післядипломної освіти 3 дисципліни "Управління та економіка фармації".

5. Навчальний посібник “Фармацевтичне право”. "Порядок перевірок контролюючими органами". "Перевірки у сфері захисту прав споживачів".

6. Навчально-методичний посібник "Долікарська допомога при невідкладних станах".

7. Навчально-методичний посібник "Принципи лікування гострих отруєнь”.

В даний час готуються нові навчально-методичні посібники $з$ клінічної фармації гормональних контрацептивів і УЕФ, зокрема, з маркетингу у фармації для провізорів-курсантів. Оновлені лекції з управління та економіки фармації. Складено і написано 8 нових лекцій з урахуванням сучасних аспектів клінічної фармакології 3 клінічної фармації. Підготовлено близько 200 нових тестів 3 клінічної фармації.

На кафедрі фармакогнозії, фармацевтичної хімії та технології ліків також розроблені робочі програми 3 відповідних дисциплін за фахом “Загальна фармація”, “Організація та управління фармацією”, “Аналітично-контрольна фармація”. Крім того, розроблені навчально-методичні та навчальні посібники:

1. Навчально-методичний посібник "Кисневі фітококтейлі в сучасній фітотерапії’.

2. Навчально-методичний посібник “Екологічні терміни з курсом фармакогнозіі”.

3. Навчальний посібник "Аптечна технологія лікарських форм, що готуються асептично”.

4. Навчальний посібник "Приготування м'яких лікарських форм в аптечних умовах".

Підготовлено "Довідник-посібник з виробництва лікарських засобів” для курсантів та інтернів.

Таким чином, в Запорізькому державному медичному університеті $€$ всі умови для проведення передатестаційних і тематичних курсів удосконалення провізорів.

Слід зазначити, що в Запорізькому державному медичному університеті курси підвищення кваліфікації ведуться викладачами двох фармацевтичних кафедр ФПО, а також викладачами основних (що випускають) кафедр медичного університету - управління та економіки фармації, технології ліків, фармацевтичної хімії і фармакогнозії. Крім того, коли вступив в дію наказ МО3 України № 398 від 08.10. 2001 року "Про впровадження удосконалених автоматизованих атестаційних систем", для проведення курсів були залучені ресурси кафедри медичної інформатики. На кафедрі клінічної фармації, фармакотерапії і управління та економіки фармації лекції, семінари та практичні заняття проводять викладачі: 1 професор, 1 доцент, 1 старший викладач та 3 асистенти. На кафедрі фармакогнозії, технології ліків та фармацевтичної хімії ФПО на курсах удосконалення задіяні всі викладачі.

На виїзних курсах з клінічної фармації, УЕФ, фармакогнозії, технології ліків та фармацевтичної хімії лекції та практичні заняття (семінари) проводять провідні викладачі (завідувачі кафедр ФПО, доценти).

На основі наказу МОЗ України № 818 від 12.12. 2006 "Про атестацію провізорів та фармацевтів" навчальний процес проводиться відповідно до затверджених MO3 України програм підготовки провізорів передатестаційних циклів підвищення кваліфікації за фахом “Загальна фармація”, “Аналітично-контрольна фармація”, “Організація та керування фармацією”, затвердженим Запорізьким державним медичним університетом, а також програм тематичного удосконалення провізорів, фармацевтів і фахівців промислових підприємств хімічного профілю. 
Організація навчального процесу на кафедрі клінічної фармації, фармакотерапії та УЕФ ікафедрі фармакогнозіі, фармацевтичної хімії та технології ліків передбачає розробку, обговорення і затвердження робочої програми 3 усіх провідних дисциплін: клінічноїфармації, управління та економіки фармаціі, фармакогнозіі, фармацевтичної хімії та технології ліків, а також складання календарних планів, лекцій, практичних занять, семінарів та навчально-методичних вказівок. При цьому велика увага приділяється комп'ютерному тестуванню знань за програмою "Елекс" на кафедрі інформатики слухачів ФПО під час іспитів 3 дисциплін, що вивчаються.

Слід сказати, що зміст робочих програм, які використовуються в навчальному процесі для провізорів-

\section{Література}

1. Сучасний розвиток вищої медичної освіти й проблеми питання забезпечення якісної підготовки лікарів і провізорів / М. В. Банчук, О. П. Волосовець, І. І. Фещенко [та ін.] // Медична освіта. - 2007. - № 2. - С. 5-13.

2. Вороненко Ю. В. Фактори реформування післядипломної освіти / Ю. В. Вороненко, О. П. Мінцер // Проблеми безперервного розвитку лікарів і провізорів : матеріали науково-методичної конференції з міжнародною участю. К., 2007.-C. 27-29.

3. Минцер О. П. Трансфер знаний при дистанционных формах обучения / О. П. Минцер // Матер. наук.-практ. конф. “Актуальні питання дистанційної освіти та телемедицини”. - Запоріжжя, 2008.

4. Методичні основи підготовки і проведення навчальних занять в медичних вузах : методичний посібник. - К. : курсантів, повністю відповідає тематиці діючої навчальної програми та охоплює всі розділи клінічної фармації, управління та економіки фармації, фармакогнозіі, фармацевтичної хімії та технології ліків.

Відповідно до дисциплін навчальний план і програма передатестаційних курсів підвищення кваліфікації за спеціальністю "Провізор” містить шість розділів.

Висновок. Таким чином, навчання на курсах дає можливість провізорам отримати широку фундаментальну науково обгрунтовану практичну підготовку 3 урахуванням сучасних досягнень 3 фахових дисциплін: управління та економіки фармації, технології ліків, фармацевтичної хімії, клінічної фармації, медичної інформатики.

Хрещатик, 2007.-76 c.

5. Ковальчук Л. Я. Концептуальні підходи до інтегрального середовища оцінки знань у медичній освіті / Л. Я. Ковальчук, А. В. Марценюк, А. В. Семенець // Клин. информат. и телемед. -2008. - Т. V, вып. 5. - С. 71-76.

6. До питання самостійної роботи провізорів-інтернів за спеціальністю “Загальна фармація” / Т. В. Торхова, Р. С. Коритнюк, К. Л. Давтян [та ін.] // Проблеми інтеграції української медичної освіти у світовий освітній простір : матеріали Всеукраїнської навчально-наукової конференції. - Тернопіль : ТДМУ, 2009. - 314 с.

7. Проблеми інтеграції української медичної освіти у світовий освітній простір : матеріали Всеукраїнської навчально-наукової конференції. - Тернопіль : ТДМУ, 2009. $314 \mathrm{c}$. 